\title{
Comparative Study of the Dyes Induced Citotoxicity in Cultures of Cerebelar Granular Neurons
}

\author{
GRATIELA LIVIA MIHAI ${ }^{1}$, IOANA ANCA BADARAU ${ }^{1}$, CRISTIAN SCHEAUㄴ, MARIUS TOMA PAPACOCEA ${ }^{2}$, \\ IOANA RALUCA PAPACOCEA ${ }^{1 *}$ \\ ${ }^{1}$ Carol Davila University of Medicine and Pharmacy, Faculty of Medicine, Discipline of Physiology I, 37 Dionisie Lupu Str., \\ 020021, Bucharest, Romania \\ ${ }^{2}$ Carol Davila University of Medicine and Pharmacy, Faculty of Medicine, Neurosurgical Department of the St. Pantelimon Clinical \\ Emergency Hospital, 340-342 Pantelimon Str., 021659, Bucharest, Romania
}

\begin{abstract}
Determining neural viability in cell cultures is an essential element in both fundamental and clinical research, including testing the efficacy of certain neuroprotective drug compounds. Therefore, for a more rigorous evaluation of neuronal death associated with either experimental conditions or experimental models of neurological diseases, it is important that the research method and especially the staining method does not produce additional neural injuries and does not change the number destroyed cells. In the present study we tested how several types of dyes: Trypan Blue (TB), Calcein AM, Hoechst 33342, Propidium lodide and WST1/Formazan, affect neuronal viability in cell cultures before and after hypoxia and also, which dyes are associated with a higher percentage of cytotoxicity.
\end{abstract}

Keywords: cytotoxicity, dyes, cell cultures

The evaluation of the neuronal viability in primary cell cultures represents an essential element in both fundamental and clinical research.[1] One of the major problem in neuronal research is an accurate evaluation of the number of neurons. Classical methods of coloration may exert different effects on neuronal viability, involving a suplimentary toxic effect of the dye [2] of the solvent or both. Therefore, for a more rigorous evaluation of neuronal death associated with either experimental conditions or experimental models of neurological diseases.[3,4] It is important that the research method and especially the staining method does not produce additional neural injuries and does not change the number destroyed cells.

\section{Experimental part}

Materials and methods

Cell culture procedure

Primary cerebellar neuron cultures were prepared from the cerebella of 5 days old Wistar rats according to Stelmashook [5]. All experiments were performed in accordance with the European legislation regarding the protection of animals used for scientific purposes. We applied a three-hour ischemia test (exposure to 100\% nitrogen flush for $10 \mathrm{~s}$ followed by exposure of the culture to $4 \%$ oxygen atmosphere) to study neural viability using all three coloration methods before and after ischemia and to provide the most accurate information regarding neuronal death.
The cell viability assay method using Trypan Blue (TB) is considered the reference test in the practice of the cell culture lab $[6,7]$.

Trypan Blue (3Z, 3'Z)-3,3'-[(3.3'-dimethylbiphenyl-4-4'diyl)di(1Z)hydrazin-2-yl-1-ylidene]bis(5-amino-4-oxo-3,4dihydronaphtalene-2,7-disulfonic acid) is a highly hydrophilic azo dye with a high molecular weight that is excluded from the cytoplasm of living cells (fig.1).

TB is used to identify cell death by delayed necrosis or apoptosis. The procedure included cells washing with phosphate buffer to remove the phenol red culture medium, and then addition of $0.5 \mathrm{~mL}$ of $0.4 \%$ TB solution, at room temperature, and wait for $5 \mathrm{~min}$.

Another method of neuronal viability are fluorescent methods; measurements using fluorescent markers are commonly used in the cell culture laboratory. The cells were tested using simultaneously several fluorescent markers: Calcein AM, Hoechst 33342 and Propylium lodine, in order to maximize the content of information on cell viability [8].

Calcein AM (fig. 2) (AM = acetoxymethyl) or fluorexone is a non-fluorescent permeable dye that is hydrolyzed by intracellular esterases in a fluorescent anion. This is found in the cytoplasm of viable cells

Hoechst 33342 (2'- (4-Ethoxyphenyl) -6- (4-methyl-1piperazinyl) $-1 \mathrm{H}, 3^{\prime} \mathrm{H}-2,5^{\prime}$-bibenzimidazole) and Propidium iodide are nuclear dyes that stain the DNA (fig. 3). Hoechst

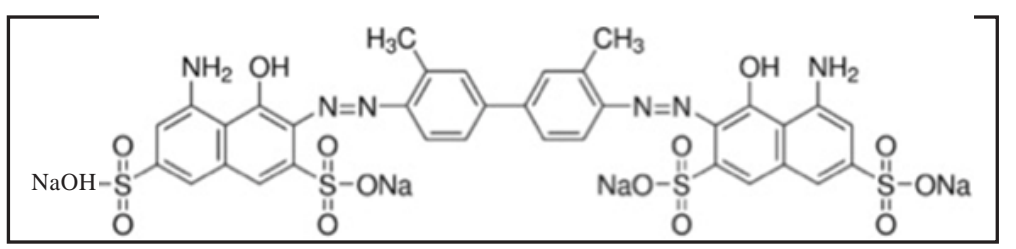

Fig. 1 Molecular structure of Trypan blue (TB) $\mathrm{C}_{34} \mathrm{H}_{24} \mathrm{~N}_{6} \mathrm{Na}_{4} \mathrm{O}_{14} \mathrm{~S}_{4^{\prime}}$ molar mass $960.81 \mathrm{~g} / \mathrm{mol}^{-1}$

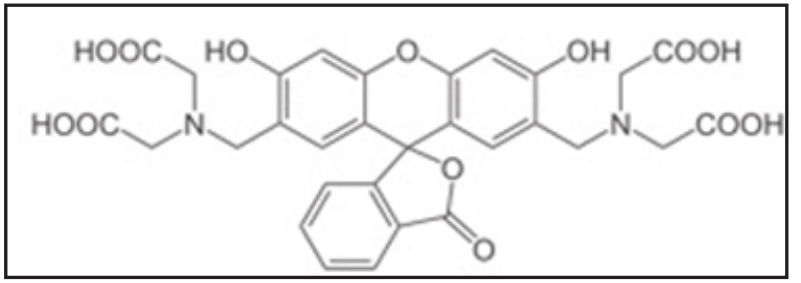

Fig. 2 Molecular structure of calcein, $\mathrm{C}_{30} \mathrm{H}_{26} \mathrm{~N}_{2} \mathrm{O}_{13^{\prime}}$ molar mass $622.55 \mathrm{~g} / \mathrm{mol}$

*email: rpapacocea@ gmail.com; Phone: +40729983332 


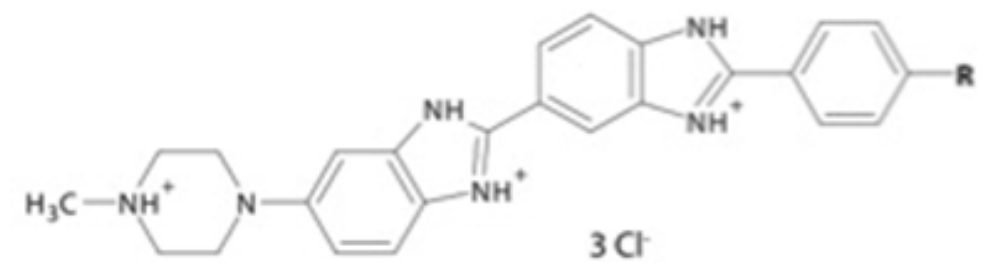

Fig.3 Molecular structure of Hoechst $33342, \mathrm{C}_{25} \mathrm{H}_{26} \mathrm{~N}_{6} \mathrm{R}$, molar mass $410.512+\mathrm{R} \mathrm{g} / \mathrm{mol}$.

33342 is permeable to the nuclear membrane and stains DNA at the Adenine - Thymine Adenine-Nitrogen Base Pair.

The principle of the method refers to marking cellular fields and then counting the cells.

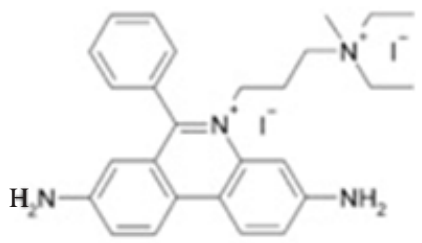

Fig.4 Molecular structure of Propidium iodide (PI), $\mathrm{C}_{27} \mathrm{H}_{34} \mathrm{I}_{2} \mathrm{~N}_{4}$, molar mass 668.3946

Another test using WST-1 (4- [3- (4-iodophenyl) -2- (4nitrophenyl) -2H-5-tetrazolio] -1,3-benzene disulphonate tetrazolium salt is a quantitative colorimetric method for the determination of cell viability based on the ability of metabolically active cells to cleave WST-1 to soluble formazan.

It has been shown that mitochondrial production of formazan depends on the source of NADH/ NADPH. However, in the absence of extracellular NADH production reactions, the production of formazan is directly proportional to the number of viable cells and to the level of metabolic activity. For this assay 10uL of WST-1 solution was added to the $100 \mu \mathrm{L}$ experimental cell culture medium in the 96-well plate. To homogenize the reagent, the culture plate was placed in a shaker (Biosan ES-20) for 2 min at $100 \mathrm{rpm}$ at room temperature. Absorbance was measured at an Expert 96 (Asys assay) spectrophotometer at 450 $\mathrm{nm}$ at $620 \mathrm{~nm}$. Initial optical density was red immediately, at $0 \mathrm{~h}$. Then the cells were incubated for $3 \mathrm{~h}$ at $37^{\circ} \mathrm{C}$ and $5 \%$ $\mathrm{CO}_{2}$. The optical density corresponding to the formation of formazan was then red. From this value, the initial optical density decreased and the final optical density was obtained.

\section{Statistic analyze}

All numeric data in text and graphics is the mean \pm SEM. Statistical analysis (two-tailed, paired Student t-test, Pearson correlation) was performed using SPSS (v 12.0.1 for Windows).

\section{Results and discussions}

For Trypan blue, the mean neuronal viability was $0.35 \%$ \pm 0.15 ( \pm SEM) versus $15.44 \% \pm 5.23$ in fluorescence only in the presence of hypoxia. The percentage of injured neurons was $11.25 \% \pm 2.13$ in TB versus $56.83 \% \pm 5.74$ in fluorescence coloration, and of dead neurons was $88.4 \%$ \pm 2.12 in TB versus $27.73 \% \pm 5.74$ in fluorescence. Production of formazan after $3 \mathrm{~h}$ of oxygen and glucose deprivation (ischemia) was $45.15 \% \pm 5.09$ over control values (fig.5).

Significant differences are noted between the results obtained with Trypan blue and fluorescence, respectively. Thus, the method using Trypan blue shows a noticeably higher percentage of dead cells vs. florescence, but also contrasting with the metabolic changes shown by the WST1 test. We suspect a destructive effect on the viability of Tripan blue itself that alters cell osmolarity. There were differences in both fluorescence and WST-1 test results. To verify this hypothesis we marked neural fields (the same neurons) and we measured the surface of the cytoplasm.

The images were imported using the Image J 1.33u software and the cell cytoplasm was measured manually using the mouse. The same procedure was applied both to the control group but also to the ischemia group in fluorescence. The results show changes in the cell surface recorded during neuronal viability determination and are expressed \pm SEM $(p<0.002)$.

Dyes used in fluorescence determine a cell surface reduction of $6.99 \% \pm 0.58$ (mean \pm SEM, $p<0.0001$ ) while TB staining induces cell surface growth by $5.97 \% \pm 1.6$ (p $<0.002$ ) in control group.

Analyzing the results obtained in fluorescence, functional cells are defined as the sum between normal and affected cells. The results obtained by the WST-1 test are more reliable than those by fluorescence (fig.6)

Investigation of the cell cultures with dyes - trypan blue to fluorescence microscopy - represents valuable techniques to evaluate morphology, cellular functionality and viability. During these processes, a carefully attention should be paid to limit cell damages, taken in account that all methods carry a risk in terms of cell viability.

That is why our study performed a comparative analyse of neuronal cells viability in normal conditions and after exposure to hypoxia, when trypan blue, calcein, Hoechst 33342, Propidium iodine and WST-1 methods were used.

In our study, trypan blue exerted toxic effect acting immediately after its application; we also showed the relation between the cytotoxic effect of trypan blue and the increase of the cell surface, especially while the cell is exposed to ischemia. In a study performed on retinal cell

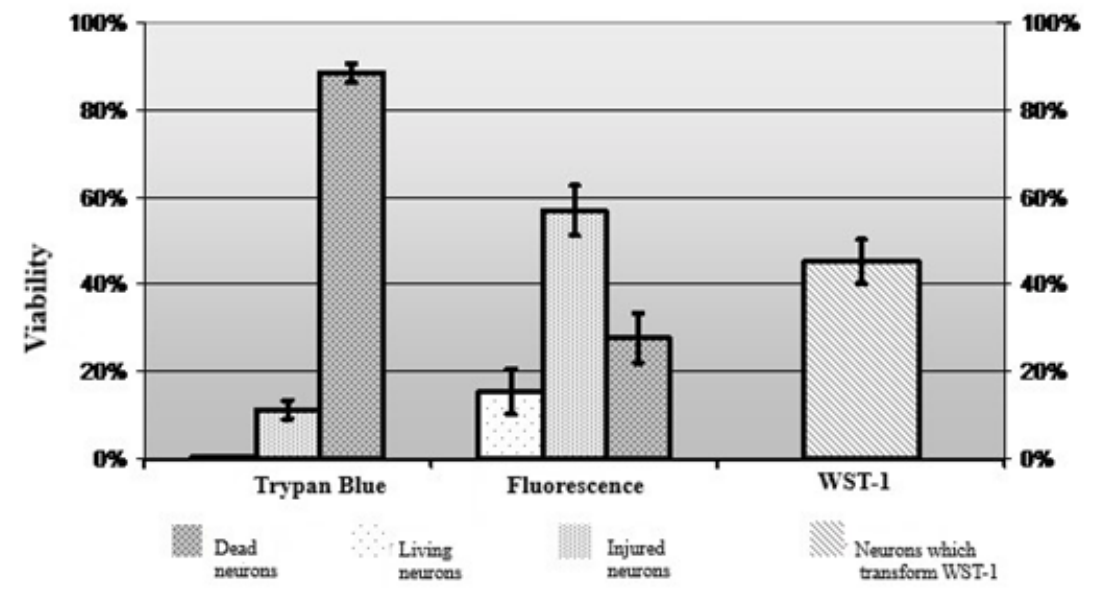

Fig.5. Neuronal viability in three-hour ischemia assessed using Trypan Blue (TB), Fluorescence and WST-1 


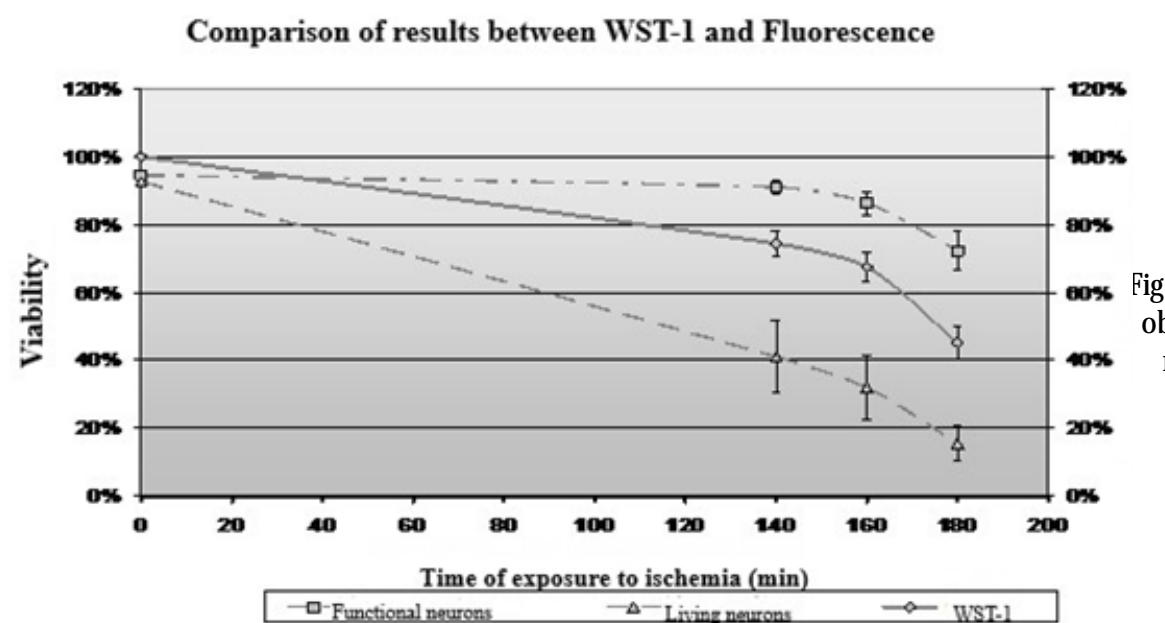

Fig. 6 Comparison of the results of neural viability obtained by fluorescence and WST-1 at different moments (minutes) of exposure to ischemia

culture, application of $0.06 \mathrm{mg} / \mathrm{mL}$ of trypan blue for 1 minut does not significant affectcells viability. Exposure to higher concentrations for a longer time reduces cell viability and induces activation of apoptotic genes $[9,10]$.

Based on this property, other author applied irradiation of tumoral cells (meningioma) in the presence of trypan blue to enhance selective tumoral cell destruction [11,12].

Sequential application of several fluorochromes, exposure to different wave light, especially ultraviolet light and successive bleaching steps may induce cellular damages from changes in the structure of the DNA chain to initiation of apoptosis [13].

Calcein AM identified viable cells following ischemia, hemorrhage or other pathological circumstances which affect cerebellar or cerebral neurons. [14-16]

Fluorescent substances induced cell death a few hours after exposure, but the first lesions appeared earlier. We showed that calcein AM application was also cytotoxic, inducing apoptosis by binding to the nuclear and/or mitochondrial DNA.

Hoechst 33342 binds cell DNA by braking DNA strand so it is involved in living cells properties and structure. More, Hoechst 33342 induces mithocondrial dysfunction, increases oxidative stress through generation of oxygen free radicals, effects which last 48 hours after exposure to dye. Following cell culture irradiation in the presence of Hoechst 33342, it was noticed a down regulation of Cytochrome C oxidase, a reduction in antioxidantenzymes expression especially for SOD and catalase. All these observations indicate a role for Hoechst 33342 in the alteration of cell viability mediated by oxidative stress. $[17,18]$

The results of the Trypan blue and fluorescence are somewhat similar in terms of the control culture and become inconsistent after deprivation of oxygen and glucose to the duration of 3 hours. Comparing the results obtained by fluorescence and WST-1, we found that they are similar in terms of metabolic activity. WST-1 test indicates the existence of the affected neurons and that they maintain a certain level of metabolic activity.

\section{Conclusions}

Trypan blue and calcein AM exert a toxic effect acting immediately after their application, through binding to nuclear and/or mitochondrial DNA. Taken together, after the same time of exposure, the most important percentage of injured neurons in the same condition were induced by trypan blue exposure versus fluorescent dyes. Particularly important are tests that evaluate neuronal metabolic activity (fluorescence, WST-1) which suggest the existence of impaired neurons (affected but able of functional recovery). These results may be applied in different experimental protocols, depending of interest/ direction of research.

Acknowledgement: All authors contributed equally to the present article, to the manuscript review and its final form approva; all authors equally are main authors.

\section{References}

1.JIAJIA, L., SHINGHUNG, M., JIACHENG, Z., JIALING, W., DILIN, X., SHENGQUAN, H., WEI, C. J OVE 123, 2017, e55442.

2.ALEXANDRU, O., GEORGESCU, A. M., DRAGOI, A., CIUREA, M. E., TAISESCU, C. I., TATARANU, L. G., DEMETRIAN, A., Rev. Chim. (Bucharest), 70, no.1, 2019, p.112-117.

3.AGEU, L., TALPOS, C., KANALAS, G., CRISAN, S., ZAMFIR, C. L., POROCH, V., ANGHEL, M., Rev. Chim. (Bucharest), 69, no.3, 2018, p.621-626.

4.PAPACOCEA, T., POPA, E., TURLIUC, D., PAPACOCEA, R. Farmacia, 67, no. 1, 2019, p. 140-145.

5.STELMASHOOK, E. V., ISAEV, N. K., PLOTNIKOV, E. Y., UZBEKOV, R. E., ALIEVA, I. B., ARBEILLE, B., ZOROV, D. B. Neurosci. Lett.,2009, 461 no.2, p.140-144.).

6.STROBER, W. Current protocols in immunology, 21, no.1, 1997, A$3 \mathrm{~B}$.

7. CORLAN, I. V., CHEVERESAN, A., VADUVA, D. B., NICA, C., FAUR, A., RUMEL, R. C., POPOVICI, R. A.,Rev. Chim. (Bucharest), 69, no.10, 2018, p.2891-2894.

8.VASINCU, D., IANCU, R. I., CHELARU, L., STOLERIU, G., COSTULEANU, M., Rev. Chim. (Bucharest),69, no.6, 2018, p.1570-1573

9.TRIPATHI, R. C., LIN, S., PHILIPS, W., TRIPATHI, B. J., CHALAM, K. V. Invest Ophthalmol Vis Sci, 46, no.13, 2005, p.5419-5419.

10.PREDA, M. CHEVERESAN, A., PINZARU, I., DOBRESCU, A., PAVEL, I. Z., VLAIA, V., SISU, E. Rev. Chim. (Bucharest), 69, no. 7, 2018, p.19071910.

11.TAKEDA, H., OKADA, M., KURAMOTO, K., SUZUKI, S., SAKAKI, H., SANOMACHI, T., KITANAKA, C. Oncotarget, 8, no.53, 2017, p.90996.

12.PAPACOCEA, T., ROSCA, T., BADARAU, A., PAPACOCEA, R., CIORNEI, C., ION, A. D. Chirurgia, 104, no.1, 2009, p.99-103.

13.TARNOK, A. Cytometry Part A, 83, no.6 ,2013, p.521-522.

14.SU, X., WANG, H., ZHU, L., ZHAO, J., PAN, H., JI, X. Neuroscience, 245, 2013, p.99-108.

15.PAPACOCEA, A., PAPACOCEA, T., DANAILA, L., ION, D., BADARAU, A., Chirurgia, 105, no.6, 2010, p.805-807.

16.PAPACOCEA, T., PAPACOCEA, A., DANAILA, L., PAPACOCEA, R., ION, D., BADARAU, A., BURAGA, M. Chirurgia, 106, no. 3, 2011, p. 309313.

17.ATHAR, M., CHAUDHURY, N. K., HUSSAIN, M. E., VARSHNEY, R. Mol cell biochem, 352, no.1-2, 2011, p. 281-292.

18.PAPACOCEA, T., BURAGA, I., PAPACOCEA, R., BADARAU, A.I., BURAGA, M., CIORNEI, C., MIHAI, G, STOIAN, I., ADAM, D. Farmacia, 62, no.6, 2014, p.1118-1125.

Manuscript received: 18.01 .2019 